\title{
Utdanning for yrkeslivet: Samsvar mellom ferdigheter det undervises i og ferdigheter som etterlyses
}

Av Ursula Småland Goth, professor NLA Høgskolen og Høyskolen Kristiania, Espen Schønfeldt, seniorrådgiver Viken fylkeskommune og Liv Oddrun Voll, førstelektor Universitetet i Oslo, Naturfagsenteret

\section{Abstrakt}

Fagopplæringen i Norge består av en kombinert opplæring mellom skole og bedrift. Hovedmodellen bygger på to års opplæring i videregående skole (vg1 og vg 2) og to år som lærling i bedrift (vg 3). Ofte oppleves overgangen fra elev til lærling som vanskelig. Studien har som mål å belyse innholdet i elektroundervisningen, sammenhengen mellom lærerens grunnkompetanse i elektro og kartlegging av arbeidslivets behov. Studien hadde en kvalitativ og, en kvantitativ tilnærming og datagrunnlaget baserer seg på 15 faglærere i videregående skole og 38 opplæringsansvarlige i bedrifter i Oslo og Akershus fylkeskommune.

Studien viser at innholdet i elektroopplæringen på yrkesfaglinjen teknisk industriell produksjon (TIP) i Oslo og Akershus er omfattende og dekker mange emner som arbeidslivet ikke vurderer som relevant for yrkesutøvelsen. Den store mengden fagområder legger i liten grad til rette for dybdelæring. Undervisningen krever ofte gode forkunnskaper i matematikk og naturfag, og dette er ikke tilpasset elevgruppens forutsetninger. Manglende fokus på sentralt fagstoff fører til at elevene manglet grunnleggende ferdigheter i sentrale fagemner ved overgang til lærlingetiden etter to år i videregående skole. 
Vi konkluderer med at elektroutdanning i TIP ikke oppnår relevant læringsutbytte for elevene ved overgang fra skole til lærlingetiden.

Nøkkelord: dybdelæring, læringsutbytte, yrkesopplæring, TIP (teknikk og industriell produksjon), elektro

\section{Abstract}

Vocational training in Norway consists of a combined training between school and apprenticeship. The main model is based on two years of training in upper secondary school (vg 1 and vg 2 ) and two years as an apprentice in a company (vg 3). The transition from student to apprentice is often perceived as difficult. The study aims to shed light on the content of electrical education, the connection between the teacher's basic competence in electrical engineering, mapping the needs of working life. The study has a qualitative and a quantitative approach and the data is based on 15 subject teachers in upper secondary school and 38 training managers in companies in Oslo and Akershus county municipalities. The study shows that the content of electrical training at TIP is extensive and covers many topics that working life does not consider relevant for professional practice. The large number of subject areas to a small extent facilitates in-depth learning. Lack of focus on key subjects leads to students lacking basic practical knowledge in key subjects during the transition to apprenticeship after two years in upper secondary school. We conclude that electrical education in vocational line of technical and industrial production (TIP) does not achieve relevant learning outcomes for students upon transition from school to apprenticeship.

\section{Innledning}

Ett av regjeringens satsingsområder er å løfte yrkesfagene (Røe Isaksen, 2018). En god yrkesopplæring kan betraktes ut fra tre ulike perspektiver: elevenes, bransjens og samfunnets behov for kompetanse. Alle tre perspektivene står like sentralt, og det er ikke nok å ivareta ett eller to av perspekti- 
vene for å få til en yrkesrelevant opplæring (Dahlback, Hansen, Haaland et al., 2011). For eleven må yrkesopplæringen oppleves relevant, gi kompetanse for framtidig yrkesutøvelse og bidra til motivasjon og innsats. Det er nær sammenheng mellom kompetanse og dybdelæring (Bruvik \& Haaland, 2020, St. Meld. 28 [2015-2016]). Dybdelæring karakteriseres av at elevene gradvis utvikler kunnskaper og ferdigheter innenfor et fagområde. Læringsprosesser som fremmer dybdelæring kjennetegnes ved at elevene får arbeide med og fordype seg i sentralt lærestoff over tid, og at de får tilbakemeldinger og utfordringer som er i takt med deres faglige utvikling (NOU 2015:8). Elever på yrkesfaglige utdanningsprogrammer har ofte et svakere skolefaglig utgangspunkt fra grunnskolen enn elever på studieforberedende utdanningsprogrammer (Bruvik \& Haaland, 2020, Dyrstad, 2017). Dette må yrkesopplæringen ta hensyn til og legge til rette for.

Arbeidslivet må erfare at opplæringen har gitt nyutdannede yrkesutøvere en kompetanse som samsvarer med den kompetansen nærlingslivet etterspør. Dagens hovedmodell for yrkesopplæring er en to pluss to-modell med to år i skole etterfulgt av to år i bedrift. Tanken bak denne strukturen var et gjensidig forpliktende samarbeid mellom skole og bedrift som skulle gi elevene mindre skolebasert opplæring og mer relevant praksis og arbeidserfaring (Nyen \& Tønder, 2012). Målet er at skole og bedrift skal samarbeide for å kunne gi opplæringen "det beste fra to verdener». Ved å ha opplæring i bedrift kan elevene bli kjent med bedriftskulturen slik at overgangen fra en teoribasert, beskyttet skoleopplæring til arbeidslivet ikke blir et 'praksissjokk' og som kan resultere i frafall (Buland \& Fonn, 2010, s. 21). I Sintefs sluttrapport om Prosjekt Vandreboka kommer det frem at elever opplever at skillet mellom skole og bedrift er stort, og at opplæringen er preget av veiskiller hvor de hele tiden må starte på nytt (Buland \& Fonn 2010). Skole og bedrift har ulike kunnskapskulturer, og overgangen mellom opplæring i skole og opplæring i bedrift er ikke uproblematisk. Det er derfor viktig at begge aktører - skole og bedrift - samarbeider for å forberede elevene og ta dem imot der elevene er (Dyrstad, 2017).

Samfunnet har behov for arbeidstakere med et bredt og variert spekter av kompetanse. Statistisk sentralbyrå har vurdert det som at det vil bli større etterspørsel etter arbeidskraft med yrkesfaglig utdanning i framtiden (NOU 2014:7, s. 112). Yrkesfagopplæringen spiller en viktig rolle i å gi lærlingene 
relevant læringsutbytte for å dekke samfunnets behov for kompetent arbeidskraft. Det er en utfordring for yrkesfagopplæringen at mange elever ikke fullfører utdanningen fordi de ikke opplever utdanningen som relevant eller ikke får lærlingeplass (Goth \& Økland, 2016).

Fagopplæringen i Norge består av en kombinert opplæring mellom skole og bedrift. Hovedmodellen bygger på to års opplæring i videregående skole (vg 1 og vg 2) fulgt av to år som lærling i bedrift (vg 3 og vg 4). Dybdelæring defineres som gradvis utviklet kunnskap som gir varig forståelse av begreper, metoder og sammenhenger i fag og mellom fagområder (Læreplan 2018). Det innebærer at elevene i yrkesfaglinjen teknisk industriell produksjon (TIP) har mulighet til å reflektere over egen læring og bruker det vi har lært på ulike måter i kjente og ukjente situasjoner, alene eller sammen med andre de første to årene i vg 1 og vg 2 før overgang til vg 3.

Mindre stoff om mange ulike temaer gir mindre dybde (Bruvik \& Haaland, 2020), og offentlige utredninger viser at utfordringen er at fagene i skolen er oppdelt i for mange ulike temaer (NOU 2014:7, NOU 2015:8, Stortingsmelding 28). Denne stofftrengselen kan føre til at lærere ikke klarer å legge til rette for dybdelæring (Pellegrino \& Hilton, 2012). Dette begrunnes med at det blir for mye lærestoff elevene skal igjennom i det enkelte fag, noe som fører til at strofftrengselen fører til redusert mulighet til å bygge forståelse for fagenes begreper og sammenhenger. Undervisning som fremmer dybdelæring baserer seg på muligheten til å tilegne seg kunnskap over tid (Pellegrino \& Hilton, 2012).

Ved innføringen av Kunnskapsløftet i 2006 ble 13 yrkesfaglige utdanningsprogrammer i videregående skole redusert til 9 grunnkurs (Kunnskapsdepartementet, 2006, Olsen, 2013). Den skolebaserte delen av yrkesopplæringen består av brede utdanningsprogram som fører frem til en rekke yrkesbenevnelser. Dette er begrunnet med at elevene skal få tid til å bli kjent med ulike yrkesretninger for å sikre mulighet for omvalg og gi fleksibilitet i arbeidslivet (St. Meld. 20 (2012-2013)). Utdanningsprogrammet Teknisk Industriell Produksjon (TIP) fører frem til hele 60 ulike fagbrev (VilBli, 2019). Det har dermed en svært bred inngang sammenlignet med de andre yrkesfaglige utdanningsprogrammene. Selv om utdanningsprogrammet TIP fører frem til en rekke yrker, finnes det konkrete kunnskaper og ferdigheter 
som er felles og etterspurt i de yrkene som rekrutterer flest lærlinger (Goth, Landmark \& Schønfeldt, 2014).

Kompetansemålene i læreplanverket LK06 er utformet på en slik måte at de skal være relevante for alle yrkene som inngår i utdanningsprogrammet. Dette gir vide og generelle kompetansemål med stor frihet til tolkning og lokal tilpasning (Dalback et al., 2011). I de yrkesfaglige læreplanene er det nettopp dette handlingsrommet som skal gjøre det mulig for den enkelte skole å tilpasse undervisningen til endringer i kompetansebehovet i det lokale arbeidsliv. Dette gjør det mulig å ivareta de nasjonale føringene om at yrkesopplæringen skal være relevant, meningsfull og tilpasset den enkelte elevs læringsbehov. Intensjonen med dagens læreplan er å gi et nødvendig handlingsrom for lærere og skoleledelse. Men dette handlingsrommet er utfordrende for skolene, stiller store krav til det lokale læreplanarbeidet, og Engelsen (2009) er kritisk til at lærere ikke får tilstrekkelig veiledning i hvordan de skal arbeide med slike kompetansemål.

\section{Forskningsspørsmål}

I studien ønsket vi å se om dagens elektroopplæring i TIP er tilpasset bedriftens og dermed markedets behov. Vi ønsket også å se i hvilken grad lærerens kompetanse har betydning for innholdet i grunnopplæringen i elektro på vg1 TIP.Vi ville også se på overgangen mellom skole og bedrift og hvordan elevens kompetanse ved overgang fra vg 2 til vg 3 samsvarer med arbeidslivets behov.

\section{Forskningsspørsmålene til studien:}

1 Hva er innholdet i elektroundervisningen på vg 1 TIP, faglærerens kompetanse og hvordan tilfredsstiller læringsmålet arbeidslivets behov, legger til rette for dybdelæring og er tilpasset elevenes forutsetninger?

2 Finnes det en sammenheng mellom lærerens grunnkompetanse i elektro, kartlegging av arbeidslivets behov og relevant elektroopplæring? 
Ursula SmÅland Goth, Espen Schønfeldt, Liv Oddrun Voll

3 Hvordan samsvarer elevens kompetanse ved overgang til vg 3 med arbeidslivets behov?

\section{Metode og teoretiske vinklinger}

Data som ble inkludert i studien baserer seg på et litteratursøk, en spørreskjemaundersøkelse med opplæringsansvarlige i bedriften og lærere i videregående skole.

\section{Litteratursøk:}

Det ble gjennomført et strukturert litteratursøk (Patton, 2015) med søkeord «TIP ", «yrkesfag» og «arbeidslivets behov». Søket ble begrenset til fagfellevurderte tidsskrifter og rapporter i perioden 2010-2020 i databasen Embase (via Ovid). Søket gav 39 treff, hvorav kun fem artikler viste seg for å være tematisk relevante og ble brukt i diskusjon av våre funn.

\section{Spørreskjema:}

Spørreskjemaet ble distribuert i papirformat under intervju. Spørsmålsutformingen ble basert på tilbakemeldinger fra opplæringskontorene i Oslo, Akershus og Østfold, lærebøker og data fra litteratursøket.

I tillegg til fellesspørsmål som ble brukt i både del 1 og del 2 fikk:

- Informantene i del 1 (faglærere i videregående skole) spørsmål om emnene ble undervist i eller ikke, men ikke hvor mye tid de brukte på hvert emne.

- Informantene i del 2 (opplæringsansvarlige i bedrift) spørsmål om å kategorisere de 95 emnene i tre kategorier: «viktige for yrkesutøvelsen», «kjekt å kunne» eller «ikke relevant». Spørreskjema ble testet og kalibrert hos åtte opplæringsansvarlige før studien ble gjennomført. 


\section{Del 1 - spørreundersøkelse med programfaglarere}

Datainnsamling i delstudien 1 er basert på et spørreskjema med 95 ferdigheter og kunnskapsområder og det ble foretatt strukturerte intervjuer med 15 faglærere (TIP). Spørreskjemaet som lå til grunn for undersøkelsen finnes i appendix A. Undersøkelsen ble gjennomført i Oslo og Akershus fylke, og vi konsentrerte studien om faglærere som underviser i elektro på vg 1 TIP.

I tillegg til spørreskjema ble det også innhentet bakgrunnsdata fra 13 av de 15 lærerne om egen kompetanse, bruk av læremidler og omfang av undervisning (se appendix B). De 15 inkluderte faglærerne var ansatt ved videregående skoler i Oslo og Akershus og utgjør $50 \%$ av alle faglærerne som underviser i elektro på vg 1 TIP i Oslo og Akershus. Etter å ha mottatt informasjon om studien var alle forespurte faglærere villig til å delta og ble inkludert i studien etter å ha signert informert samtykke.

\section{Del 2 - spørreundersøkelse med opplaringsansvarlige i bedriftene}

Delstudien 2 ønsker å kartlegge en mulig sammenheng mellom lærerens grunnkompetanse i elektro, kartlegging av arbeidslivets behov og relevant elektroopplæring. Videre ønsket forfatterne i undersøkelsen å belyse hvordan elevens kompetanse ved overgang til vg 3 samsvarer med arbeidslivets behov.

Delstudien 2 er basert på en spørreundersøkelse som inkluderte 38 opplæringsansvarlige som representerer de fire fagområdene: Bilfag lette kjøretøy (11 informanter), Bilfag tunge kjøretøy (11 informanter), Motormenn (7 informanter) og Industrimekaniker (9 informanter). Spørreundersøkelsen for del 2 besto av to deler, et kvantitativ del (appendix A) og en kvalitativ del (appendix B).

\section{Analyse}

Data fra den kvalitatative delen ble notert i spørreskjemaet og deretter kvanitifisert gjennom en matematisk analyse. I denne delstudien definerte vi en kunnskap og ferdighet som relevant hvis mer enn $20 \%$ av informantene hadde definert den som «viktig for yrkesutøvelsen». Data fra den kvalitative delen ble sammenfattet og deretter meningsfortettet av forfatterne. Det analytiske rammeverket for kvalitative data ble basert på meningsfortetning og 
meningskategorisering ved å komprimere dataene for å få økt oversikt over datamaterialet (Malterud, 2017; Kvale \& Brinkmann, 2015). For å ivareta størst mulig grad av validitet ble resultatene primært analysert individuelt av forfatterne før samanalysering fant sted.

\section{Etiske vurderinger}

Alle inkluderte informanter ble informert før de gav sitt informerte samtykke (muntlig) om å delta i studien. Alle data ble behandlet anonymt og kan ikke knyttes til personopplysninger via kode eller koblingsnøkkel.

\section{Metodekritikk}

Studien kartlegger et programfag (elektro i TIP) i vg 1 og overgang til vg 3, men inkluderer ikke vg 2. Den omfatter derfor ikke hele studieforløpet innen fagområdet. Resultatene kan bare brukes til å vurdere relevans i grunnopplæringen i elektro (vg 1).

\section{Resultat}

Innholdet og relevans $i$ elektroundervisning på vg1 TIP

Tabell 1 viser hvilke ferdigheter og kunnskapsområder som bedriftene anser som henholdsvis viktig og ikke viktig for framtidig yrkesutøvelse. I tabell 1 sammenlignet vi lærernes undervisning (L1-L15) i elektro på vg 1 TIP med det bedriftene anser som relevant. Her har vi lagt til grunn at en kunnskap og ferdighet er relevant dersom mer enn $20 \%$ av våre informanter fra bedriftene anser det som «viktig for yrkesutøvelsen». 
Tabell 1: Antall ferdigheter som undervises versus antall ferdigheter som etterspørres

\begin{tabular}{|l|c|c|c|c|c|c|c|c|c|c|c|c|c|c|c|}
\hline Lærer 1-15 & L1 & L2 & L3 & L4 & L5 & L6 & L7 & L8 & L9 & L10 & L11 & L12 & L13 & L14 & L15 \\
\hline $\begin{array}{l}\text { Antall ferdigheter og } \\
\text { kompetanse- } \\
\text { områder som } \\
\text { undervises }\end{array}$ & 58 & 62 & 53 & 51 & 26 & 73 & 51 & 57 & 42 & 77 & 60 & 22 & 51 & 54 & 66 \\
\hline $\begin{array}{l}\text { Antall ferdigheter og } \\
\text { kompetanseområder } \\
\text { som undervises, } \\
\text { men som bedrifter } \\
\text { ikke anser som } \\
\text { relevant }\end{array}$ & 12 & 15 & 7 & 11 & 2 & 21 & 16 & 9 & 5 & 25 & 11 & 1 & 12 & 8 & 21 \\
\hline $\begin{array}{l}\text { Undervisning som } \\
\text { bedriftene ikke anser } \\
\text { som relevant (i pro- } \\
\text { sent) }\end{array}$ & 21 & 24 & 13 & 22 & 8 & 29 & 31 & 16 & 12 & 32 & 18 & 5 & 24 & 15 & 32 \\
\hline
\end{tabular}

Tabell 1 er basert på data fra spørreskjema (appenix Aog B) og ble sammenfattet og dokumentert i appendix D. Appendix D viser antall ferdigheter og kunnskapsområder som undervises av lærerne 1-15 og deres selvrapporterte omfang og innhold i elektroundervisning.

Det framgår av tabell 1 at av de 95 kunnskaper og ferdigheter som inngår i spørreskjemaet, varierer antallet som underviser mellom 22 og 77. Det innebærer at innholdet i elektroundervisningen varierer mye mellom lærerne. Tabell 1 sammenligner deretter antall kunnskaper og ferdigheter læreren underviser i versus antall ferdigheter og kunnskapsområder som bedriftene anser som relevant. Her ser vi at prosentandel varierer mellom $5 \%$ og 32 $\%$. De lærerne som underviser i flest tema, har også størst prosentandel «ikkerelevant» undervisning. 
Ursula Småland Goth, Espen Schønfeldt, Liv Oddrun Voll

Antall timer avsatt til undervisning i hver av de ulike ferdighetene og kunnskapsområdene inngår ikke i datasettet.

Sammenheng mellom larernes yrkeskompetanse i elektro og gjennomforing av elektroopplaring i vg 1

Spørreundersøkelsen belyser sammenhengen mellom lærernes grunnkompetanse og antall timer elektroundervisning som tilbys den enkelte elev. Studien omfatter ikke undervisning som er gitt på vg 2 .

Tabell 2: Sammenheng mellom larerens grunnkompetanse i elektro, kartlegging av arbeidslivets behov og relevant elektroopplaring

\begin{tabular}{|l|r|r|}
\hline & $\begin{array}{l}\text { Faglærer med yrkes- } \\
\text { kompetanse* }\end{array}$ & $\begin{array}{l}\text { Faglærer uten } \\
\text { yrkeskompetanse }\end{array}$ \\
\hline Antall lærere som har besvart** & 64 & 59 \\
\hline $\begin{array}{l}\text { Antall undervisningstimer i elektro på } \\
\text { vg 1 TIP (i gjennomsnitt) }\end{array}$ & 49 & 58 \\
\hline $\begin{array}{l}\text { Kunnskaper og ferdigheter som under- } \\
\text { vises (i gjennomsnitt) }\end{array}$ & 18 & 22 \\
\hline Prosent ikke relevant (i gjennomsnitt) & 4 & 2 \\
\hline Kartlagt industriens behov & & \\
\hline
\end{tabular}

* yrkeskompetanse er definert som utdanning innen elektro eller elektro som del av fagbrev

** 2 av de 15 larerne som deltok $i$ undersøkelsen besvarte ikke spørsmål om yrkeskompetanse

Tabell 2 viser forskjell på innholdet i elektroundervisning mellom lærere med og uten yrkeskompetanse i elektro (appendix D). Yrkeskompetanse er her definert som at læreren har utdanning innen elektro eller at elektro er en del av lærerens fagbrev. Tabellen viser hvor mange timer lærere i de to kategoriene 
i gjennomsnitt bruker på elektroundervisning i vg 1 TIP totalt gjennom året. Tabellen viser også hvor mange kunnskaper og ferdigheter som undervises i løpet av disse timene, og hvor stor del av undervisningen som anses relevant av de opplæringsansvarlige fra bedriftene. Det kommer frem at det er en sammenheng mellom lærerens kompetanse og innholdet i elektroundervisning på vg 1 TIP. Av de 15 lærerne som deltok i undersøkelsen, var det 13 som besvarte spørsmål om egen kompetanse. Tabellen viser at 8 lærere har elektro som en del av eget fagbrev mens fem lærere ikke har det. Vår undersøkelse viser at faglærere med yrkeskompetanse i elektro bruker flere undervisningstimer til dette fagområdet. I gjennomsnitt bruker lærere med yrkeskompetanse i elektro 64 timer til elektroundervisning, mens lærere uten yrkeskompetanse bruker 39 timer. Lærere med yrkeskompetanse underviser også i betydelig færre emner. Det vil si at lærerens yrkeskompetanse har stor betydning for om elevene får anledning til å fordype seg over lengre tid innen hvert emne. Data mellom de to gruppene viser hvor stor andel av undervisningen som brukes på ferdigheter og kompetanseområder som bedriftene ikke anser som relevant. Hos våre informanter ser vi ingen sammenheng mellom kartlegging av bedriftenes behov og grad av relevant undervisning.

\section{Elevens kompetanse og arbeidslivets behov}

Tabell 3 oppsummerer opplæringsansvarliges opplevelse av lærlingenes kompetanse i fire helt grunnleggende kunnskaper og ferdigheter (se appendix B).

Tabell 3: Opplaringsansvarliges opplevelse ved overgang til vg 3

Kompetanse når lærling begynner i læren (vg 3) Oppgis i \%*

Hvor stor andel av lærlingene kan bruke et multimeter $39 \%$

Hvor stor andel av lærlingene kan foreta en spenningsfallmåling $26 \%$

Hvor stor andel av lærlingene kan Ohms lov

Hvor stor andel av lærlingene kan lese elektriske tegninger

*Prosent viser til et estimert antall larlinger som behersker den aktuelle ferdigheten 
Som det fremgår i tabell 3, behersket opp til 2/3 av lærlinger ikke grunnleggende ferdigheter som anses av bedriftene som en forutsetning for oppstart i vg 3 (lærlingeperioden).

For å illustrere omfanget siterer vi her noen utsagn:

Elevene kan ikke multimeter. De kan ikke stille inn og vite hva de faktisk måler. Det må sitte. Kan ikke gjøre det en gang - da glemmer man det. Det må terpes.

Opplæringsansvarlig 3, Lette kjøretøy

[Elevene] har ikke forventning om at de skal kunne så mye. Men det hjelper veldig hvis det grunnleggende er på plass. Koblingsskjema er viktig.

Opplæringsansvarlig 4, Lette kjøretøy

Det var spesielt lærlingens ferdighetsnivå som ble påpekt. De opplæringsansvarlige gav uttrykk for at de ikke opplevde ferdighetsnivået ved overgang til vg 3 som tilfredsstillende. Dette ble beskrevet som manglende grunnleggende kompetanse. To opplæringsanvarlige beskrev det slik:

Elevene mangler systemforstålse. De har ikke grunnleggende forståelse.

Opplæringsansvarlig 1, Tunge kjøretøy

Har teoretisk kunnskap, men kan ikke anvende det i praksis.

Opplæringsansvarlig 3, Tunge kjøretøy

Etter gjennomgang av 38 intervjuer med opplæringsansvarlige finner vi derimot seks ferdigheter og kunnskapsområder som opplæringsansvarlige mener er helt sentrale, men hvor lærlingene mangler grunnleggende kompetanse etter vg 2: 1) å kunne bruke Ohms lov i praksis, 2) kunne bruke et multimeter, 3) kunne lese og bruke et koblingsskjema, 4) ha systemforståelse, 5) kunne anvende feilsøkingsmetodikk og 6) grunnleggende systemforståelse i digitalteknikk (bus-signal). 


\section{Diskusjon}

Innholdet i elektroundervisning i vg 1 (TIP) og relevans i forhold til arbeidslivets behov, tilrettelegging for dybdelæring og tilpasning til elevens forutsetninger

\section{Ulike kunnskapskulturer}

Data fra de opplæringsansvarlige viser hvilken type kompetanse bedriftene opplever som viktig for yrkesutøvelsen (appendix C). Det viser seg at bedriftene legger vekt på den praktiske og utøvende kompetanse i fagområdet elektro. Eksempel på kompetanser som de opplæringsansvarlige vurderer som viktige er: «koble til og fra en elektromotor» eller «vite når og hvordan man kan bruke et multimeter til å måle motstand». De legger ikke vekt på typisk elektrisitetskunnskap fra skolens naturfag som å «beregne matematisk motstanden i parallellkoblede eller seriekoblede kretser». Det de opplæringsansvarlige betrakter som viktig for yrkesutøvelsen kan man kalle typisk teknologisk kunnskap. I skolen er opplæring i elektrisitet en del av et naturfag som baserer seg på naturvitenskapelig kunnskap. Teknologi og naturvitenskap er forskjellige fagområder med ulike fagtradisjoner. Naturvitenskapens mål er å forstå verden, mens teknologiens mål er å løse praktiske problemer. Vi kan si at vitenskapen er preget av «know why» og teknologien av «know how» (Sjøberg, 2009). Naturvitenskapelig kunnskap ligger ofte til grunn for teknologisk kunnskap, men den teknologiske kunnskapen har en mer anvendt form (Bungum, 2003). For eksempel vil naturvitenskapelig kunnskap være utgangspunkt for beregning av dimensjon og ledeevnen til en strømførende kabel. En teknolog vil slå dette opp i en tabell når han/hun skal velge hvilken kabel som skal anvendes. De opplæringsansvarlige i denne undersøkelsen betrakter ikke den naturvitenskapelige kunnskapen og forståelsen som ligger til grunn for den teknologiske, som viktig for yrkesutøvelsen. Bedriftene verdsetter "know how» i større grad enn "know why».

Forskerne Buland og Fonn (2010) peker på at skolen og bedriftene har ulike kunnskapskulturer. Skolens overordnede mål er å legge til rette for læring og utdanning og klasserommet er det viktigste stedet hvor læring skal foregå. Et skolastisk syn på kunnskap har tradisjonelt rådet innenfor det 
norske utdanningssystemet (Wackerhausen, 1999). Innenfor det skolastiske synet ser man på kunnskap som noe man tilegner seg gjennom skriftlige tekster som lærebøker og artikler, eller gjennom verbal undervisning og forelesning (Wackerhausen, 1999).

Den norske yrkesopplæringen krever at skole og bedrift samarbeider for å skape et sammenhengende fireårig opplæringsløp (Buland \& Fonn, 2010). Vår undersøkelse viser at det er til dels store avvik mellom hvilke ferdigheter og kunnskapsområder som undervises i fagområdet elektro og den kompetansen bedriftene etterspør. Det kan tyde på at aktørene er preget av den ulikhet i kunnskapskultur som er mellom de to delene av opplæringen. Skolens undervisning er preget av en naturvitenskapelig forståelse av emnet elektrisitet mens bedriftene har en mer teknologisk og anvendt tilnærming.

\section{Dybdelering}

Dybdelæring handler om at elevene utvikler sine kunnskaper og ferdigheter, at de utvikler god og varig forståelse og greier å bruke det de har lært. Hovedprioriteringene i St. Meld. 28 (2015-2016) knyttes til hvordan elever i den norske skolen skal tilegne seg kunnskaper og kompetanser de kan anvende ute i samfunnet. Ludvigenutvalgets to utredninger trekker også frem behovet for dybdelæring (NOU 2015:8; NOU 2014:7). Utvalget legger til grunn at dagens læreplan preges av for mange læringsmål uten indre faglig sammenheng.

Det tar lang tid å øve inn en ny prosedyre eller ferdighet (Dreyfus, 2004). Læringsprosesser som fremmer dybdelæring, kjennetegnes ved at elevene får fordype seg og jobbe med lærestoffet over tid, og at de får tilbakemeldinger og utfordringer som er i takt med deres faglige utvikling. Elevenes mentale bearbeiding av lærestoff kan deles inn i tre kategorier (Pellegrino \& Hilton, 2012): Utenforliggende prosessering som ikke tjener læringsmålene og virker forstyrrende, viktig prosessering som er mental bearbeiding av sentralt fagstoff og nødvendig for å forstå fagstoffets kompleksitet, og skapende prosessering som er mental organisering av kunnskap, knytte det til eksisterende forkunnskaper og utvide mentale skjema.

Det Pellegrino og Hilton (2012) kaller «utenforliggende prosessering» kan betraktes som støy som tar fokus bort fra arbeid med kjerneelementene 
i faget. Våre data viser at $20 \%$ av de ferdigheter og kunnskapsområder som lærerne underviser i, ikke betraktes av de opplæringsansvarlige som relevant eller «viktig for yrkesutøvelsen». I denne sammenhengen er dette eksempel på slik «utenforliggende prosessering» som tar fokus bort fra praktiske emner som er viktige for yrkesutøvelsen.

Dette gjelder særlig når disse ferdigheterne og kunnskapsområdene er faglig krevende og krever stor grad av elevenes mentale kapasitet (Pellegrino \& Hilton, 2012). I yrkesopplæringen må man ta utgangspunkt i at elever på yrkesfaglige utdanningsprogrammer har et svakere skolefaglig utgangspunkt fra grunnskolen enn elever på studieforberedende utdanningsprogrammer (St. Meld. 20 (2012-2013). Statistikk fra Utdanningsdirektoratet (2014) viser at elevene på yrkesfaglige studieprogram særlig har mangelfulle kunnskaper i matematikk. Flere av læringsmålene bedriftene ikke mener er viktige, kjennetegnes av at de krever god naturvitenskapelig og matematisk forståelse. Slike læringsmål virker ekstra forstyrrende for dybdelæring fordi de i liten grad er tilpasset elevenes forutsetninger.

Sammenheng mellom larerens grunnkompetanse i elektro i forhold til arbeidslivets behov og det som blir ansett som relevant elektroopplaring

Relevans er en av nøkkelbetingelsene knyttet til reformer i undervisning. Relevans brukes ofte av beslutningstakere, læreplanutviklere og forskere. I de senere år har mange politiske dokumenter basert på internasjonale undersøkelser hevdet at opplæring ofte betraktes som irrelevant for og av elevene (Stuckey, Hofstein, Mamlok-Naaman et al., 2016). Her oppfattes 'relevant' vanligvis som utilstrekkelig konseptualisert og står for forskjellige betydninger (ibid). I denne studien har vi definert kunnskaper og ferdigheter som relevante dersom mer enn $20 \%$ av bedriftsinformantene har definert det som «viktig for yrkesutøvelsen».

Yrkeslærere har ulik fagbakgrunn. For å bli tilsatt som yrkesfaglærer må man ha relevant utdanning innen de fagene yrkesutdanningsprogrammet utdanner for (Lov om opplæringsloven, 2016). Men det er ikke nødvendig å ha utdanning eller fagbrev i alle fagene som inngår i yrkesprogrammet. Denne studien har fokus på yrkesopplæringen i elektro. Vi har ønsket å stu- 
dere om det bidrar til større relevans i opplæringen dersom yrkesfaglærer har elektro som del av sitt fagbrev.

Kompetansemålene i de fagspesifikke læreplanene er vide og generelle. Grunnen er at de skal kunne tilpasses de endringer som til enhver tid foregår i hver enkelt bransje og i samfunnet generelt. Lokalt arbeid med læreplaner skal sikre at opplæringen kan tilpasses behovet til det lokale næringslivet i regionen. I tillegg er metodefriheten stor. Dette gjør at handlingsrommet for hver enkelt lærer, skole og bedrift er stort. Å tilrettelegge for opplæring i tråd med Kunnskapsløftets intensjoner krever at lærerne og instruktørene kjenner læreplanverket i sin helhet, og at de kjenner kompetansebehovet innen de yrkene utdanningsprogrammet kvalifiserer for (Dahlback et al., 2011). Intensjonen med dagens læreplan er å gi et nødvendig handlingsrom for lærere og skoleledelse. Men dette handlingsrommet er utfordrende for skolene, og stiller store krav til det lokale læreplanarbeidet. Britt Ulstrup Engelsen (2009) beskriver målene som mangetydige, at det er vanskelig for lærere å velge innhold i undervisningen og stiller seg kritisk til at lærere ikke får tilstrekkelig veiledning i hvordan de skal arbeide med slike kompetansemål.

I «Prinsipp for opplæring» (LK06) står det at godt samarbeid mellom skole og nærings- og arbeidsliv og andre deler av lokalsamfunnet kan gjøre opplæringen i fagene mer konkret og virkelighetsnær. Det kan også medvirke til at opplæringen blir oppdatert med utgangspunkt i behovene arbeidslivet har.

\section{Elevenes laringsutbytte ved overgang til vg 3 (bedrift)}

De yrkesfaglige utdanningsprogrammene i videregående skole utdanner for en hel rekke ulike yrker. Spesielt gjelder dette for TIP som danner grunnlaget for hele 60 ulike fagbrev. Selv om utdanningsprogrammene er breie, er det noen sentrale kompetanseområder som er felles for alle yrkene (Goth, Landmark \& Schønfeldt, 2014). Intensjonen med to-pluss-to-modellen med to år opplæring i skole etterfulgt av to års opplæring i bedrift er at eleven/lærlingen skal erfare «det beste fra to verdener». Realiteten har derimot ofte vært beskrevet som to separate løp, der lærebedrifter tradisjonelt ofte har gitt uttrykk for at den kompetansen elevene har med seg når de blir lærlinger, ikke har vært tilstrekkelig eller har vært en annen enn den bedriftene trenger. 
I Sintefs sluttrapport om Prosjekt Vandreboka kommer det frem at elever opplever at skillet mellom skole og bedrift er stort, og at opplæringen er preget av veiskiller hvor de hele tiden må starte på nytt (Buland \& Fonn, 2010). Lærebedrifter uttrykker i rapporten at de også opplever at lærlingene ikke har den kompetansen de trenger, og at de må tilføre denne fra begynnelsen av. «De lærer ingen ting i skolen!» og «Vi må starte fra begynnelsen!» er typiske uttalelser man har kunnet møte, og fortsatt møter (ibid.).

Våre data bekrefter inntrykket av to separate løp som har manglende kjennskap til hverandre. St. Meld. 28 (2015 2016) poengterer at opplæringen må legge vekt på dybdelæring av kjerneelementene i faget. Det kan tyde på at det ikke er tilstrekkelig samsvar mellom de to delene av opplæringsløpet om hva som bør defineres som kjerneelementer.

\section{Konklusjon}

Studien konkluderer med at undervisning i elektro på videregående skole ikke gir elevene et relevant faglig grunnlag som trengs i den videre opplæringen i bedriften ved elevenes overgang til vg 3. Det tyder på at opplæring i skole ikke gir et godt faglig grunnlag for videre opplæring i bedrift og ikke i tilstrekkelig grad bidrar til dybde og progresjon i opplæringen. Elektroopplæringen på TIP i Oslo og Akershus sikrer dermed ikke i tilstrekkelig grad elevenes og arbeidslivets behov for en god yrkesopplæring.

\section{Referanseliste}

Bruvik, Å.N. \& Haaland, G. (2020). Relevant opplæring i yrkesopplæringens første år: Elevers erfaringer med yrkesrelevant opplæring. Nordic Journal of Vocational Education and Training 10(2):44-61. Doi: 10.3384/njvet.2242-458X.2010244

Buland, T. \& Fonn, K.H. (2010). Narr ulike verdener møtes : sluttrapport fra folgestudien av Prosjekt Vandreboka. SINTEF rapport A15. Trondheim: SINTEF, Teknologi og samfunn, Innovasjon og virksomhetsutvikling. 
Bungum, B. (2003). Teknolog - naturvitenskapens uekte barn? En slektsgranskning med undervisningsmessige konsekvenser. I B. Bungum \& D. Jorde (Red.), Naturfagdidaktikk: Perspektiver, forskning, utvikling (s. 389-405). Oslo: Gyldendal akademisk.

Dahlback, J., Hansen, K., Haaland, G. \& Sylte, A.L. (2011). Yrkesdidaktisk kunnskapsutvikling og implementering av nye lareplaner (KIP). Veien til yrkesrelevant opplaring fra forste dag i vg 1. Rapport 14, Lillestrøm: Høgskolen i Akershus.

Dreyfus, S.E. (2004). The Five-Stage Model of Adult Skill Acquisition. Bulletin of Science, Technology \& Society 24(3):177-181.

Doi:10.1177/0270467604264992

Dyrstad, E. (2017). Årsaker til frafall blant elever i videregående opplaring: Frafall som utviklinsprosess. Master oppgave. Univesitetet i Agder. Hentet den 20.09.2020 fra http://hdl.handle.net/11250/2459604

Engelsen, B.U. (2009). Et forskningsblikk på skoleeierne i implementeringen av Kunnskapsløftet og LK06, I E.L. Dale (Red.), Lareplan i et forskningsperspektiv. Kapittel 3. (s. 62-115). Oslo: Universitetsforlaget.

Lov om opplæringsloven. (2016). Hentet den 19.03.2020 fra https://lovdata.no/dokument/NL/lov/1998-07-17-61

Goth, U.S. \& Økland, Ø. (2016). Helse- og omsorgsutdanning i en globalisert utdanning. I Goth, U.S. (Red.). Yrkes-og profesjonsutdanning $i$ en norsk kontekst. (s. 68-78). Oslo: Gyldendal Akademisk.

Goth, U.S, Landmark, B.F. \& Schønfeldt, E. (2014). Finnes det en faglig felleskomponent for TIP yrkene? Nordic Journal of Vocational Education and Training 4(1):1-14. Doi: 10.3384/njvet.2242-458X.14v4i1

Kvale, S. \& Brinkmann, S. (2015). Det kvalitative forskningsintervju (3. utgave) Oslo: Gyldendal Norsk Forlag.

Kunnskapsdepartementet. (2006). Kunnskapsløftet. Oslo: Kunnskapsdepartementet. Hentet den 10.10.2020 fra http://www.udir.no/Lareplaner/ Kunnskapsloftet/

Læreplan. (2018). Lareplan i felles programplan i vg 1 TIP. Utdanningsdirektoratet. Hentet den 30.05.20 fra https://www.udir.no/kl06/TIP1-01

Malterud, K. (2017). Kvalitativ metasyntese som forskningsmetode i medisin og helsefag. Oslo: Universitetsforlaget. 
NOU. (2015). Fremtidens skole. Fornyelse av fag og kompetanser (2015:8). Oslo: Kunnskapsdepartementet. (Ludvigsenutvalget). Hentet den 12.05.2020 fra http://nettsteder.regjeringen.no/fremtidensskole/nouo2015-8/

NOU. (2014). Elevens laring i framtidenes skole. Et kunnskapsgrunnlag. (2014:7). Oslo: Kunnskapsdepartementet.

Nyen, T., \& Tønder, A.K. (2012). Fleksibilitet eller faglighet? : en studie av innforingen av faget prosjekt til fordypning $i$ Kunnskapsloftet. Oslo: Fafo.

Olsen, O.J. (2013) Bredde og fordypning i norsk fag- og yrkesopplæring Spenninger i/mellom utdanning, arbeidsliv og perspektiver på læring. Norsk Pedagogisk Tidsskrift 97(02): 141-153. Hentet den 01.08.2018 fra: https://www.idunn.no/npt/2013/02/bredde_og_fordypning_i_ norsk_fag__og_yrkesopplring___spenn

Patton, M. Q. (2015). Qualitative Evaluation and Research Methods. Thousand Oaks, CA: Sage.

Pellegrino, J.W. \& Hilton, M.L. (2012). Education for Life and Work. Developing Transferable Knowledge and Skills in the 21st Century. Washington, DC: National Research Academy.

Røe Isaksen, T. (2018). 2018 blir yrkesfagenes år. Hentet den 12.04.20 fra https://www.regjeringen.no/no/aktuelt/2018-blir-yrkesfagenesar/id2583726/

Sjøberg, S. (2009). Naturfag som allmenndannelse: En kritisk fagdidaktikk (3. utg.). Oslo: G Gyldendal akademisk.

St. Meld. 28 (2015-2016). Fag-Fordypning-Forståelse - En fornyelse av Kunnkapsløftet. Hentet den 12.04.2020 fra https:/www.regjeringen.no/no/ dokumenter/meld.-st.-28 20152016/id2483955/

St. Meld. 20 (2012-2013). På rett vei. Hentet den 12.04.2020 fra https:/www.regjeringen.no/no/dokumenter/meld-st-20-20122013/ id717308/sec1

Stuckey, M., Hofstein, A., Mamlok-Naaman, R. \& Eilks, I. (2013). The meaning of 'relevance' in science education and its implications for the science curriculum. Studies in Science Education.

doi:10.1080/03057267.2013.802463 
Utdanningsdirektoratet. (2014). Karakterstatistikk for 2016-17. Hovedfunn. Hentet den 24.08.2020 fra https://www.udir.no/tall-og-forskning/finnforskning/tema/karakterer/karakterer-i-videregaende/

Utdanningsdirektoratet. (2019). Statistikk om larlinger, larebedrifter og fagbrev (analyse). Hentet den 04.06.2020 fra https://www.udir.no/tall-og-forskning/statistikk/statistikk-fag--og-yrkesopplaring/antall-larlinger/larekontrakter-utdanningsprogram/

Vilbli. (2019). Yrker og kompetanser. Hentet den 04.06.2020 fra https://www.vilbli.no/nb/nb/no/laereplan-/ul/v.tp/

Wackerhausen, S. (1999). Det skolastiske paradigmet og mesterlære. I: K. Nielsen \& S. Kvale (Red.). Mesterlare: Laring som sosial praksis. (1. Utg., s. 182 -193). Oslo: Gyldendal 


\section{Appendix A}

\section{APPENDIX A}

Felles spørreskjema for bedrifter (opplæringsansvarlige) og lærere

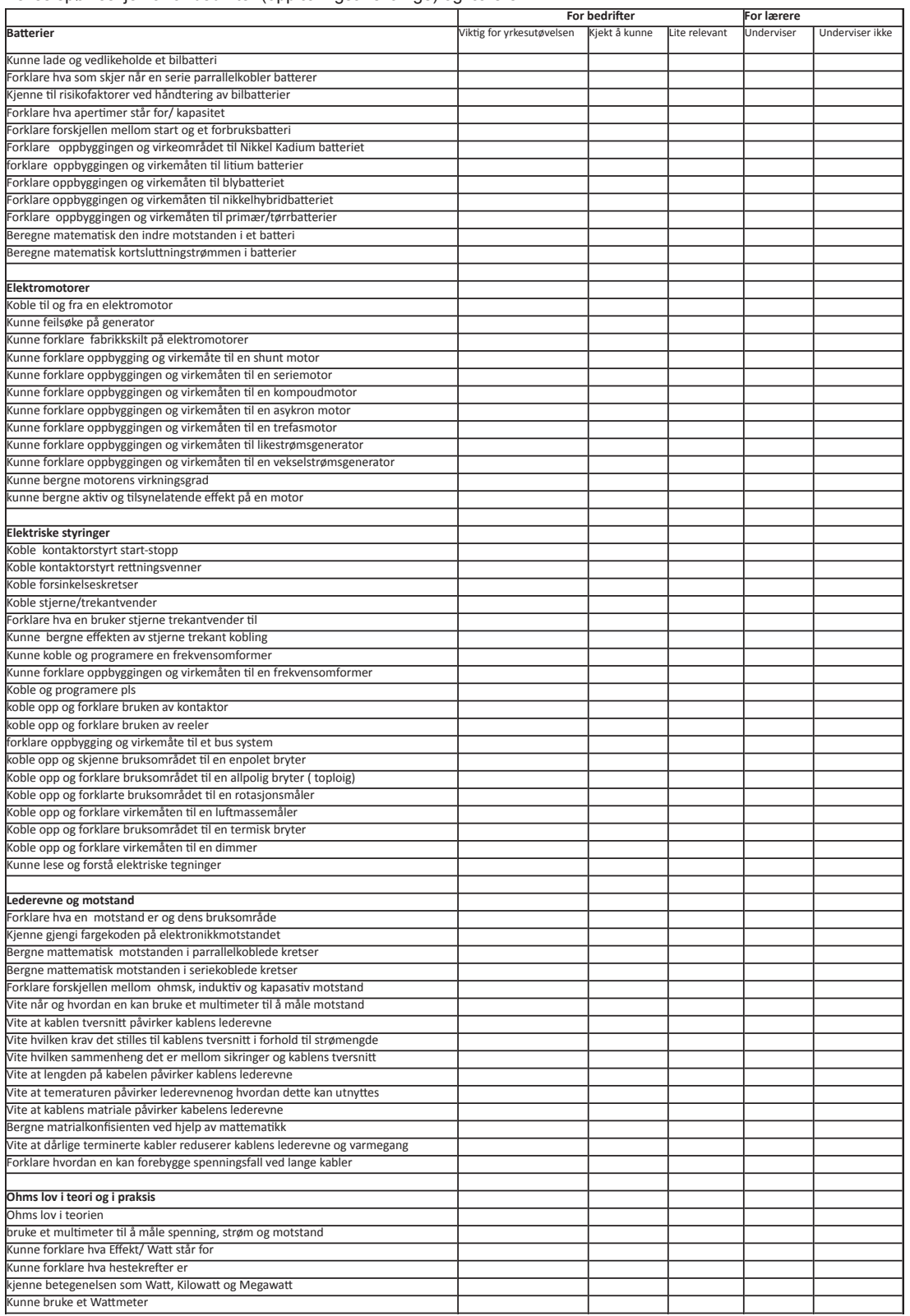




\section{APPENDIX A}

Kunne forlare hva motstand er

Kunne forklare betegelsene Ohm Kilo ohm og mega Ohm

Forklare hva strøm er

Kunne forklare begtenelsene milli amp og amp

Kunne forklare forskjellen på faktisk og teoreisk strømrettnin

Forklare bohrs atomteorier

Kunne forklare hvor en normalt bruker likestrøm og vekselstrøm

Kunne forstå begrepene amplitudeverdi og bunnverdi

Elektriske komponenter

Vite hva dioder brukes til

Teoretisk forståelse for hvordan en diode er konstruert

Vite hva transistorer brukes til

Teoretisk forståelse for hvordan en transistor er konstruert

Vite hva en likeretter kan brukes til

Teoretisk forståelse for hvordan en likeretter er konstruert

Vite hva en transformator brukes til

Teoretisk forstáelse for hvordan en transformator er konstruktert

Kondensator vite hva er

Kunne forklare kondensatorers oppbygging og virkemåte

Forklare hva styringsenheten ecu er

Vite forskjellen mellom ledlamper, fluoriserende og glødelampe

\section{Elektrisitet og sikkerhet}

Vite at hovedreglen er at en ikke har lov til å jobbe på elektriske annlegg over $50 \mathrm{v}$

Vite hva en untakksvis har tilatelse til på spenninger over 50 volt

Vite hva instruert personel har lov til og giøre og hva de ikke har lov ti

vite at kortsluttning kan føre til branne eller brannskader

Kjenne til risikoen ved å jobbe i nærheten av høyspentannlegg

Vite at sikringer er en sikkerhet mot kortsluttning og overbelastning av annle

Vite at jording kan redusere risikoen for strømgjennómgan

Vite at Jordfeilbrytere kan beskyte med farlig strømgjennomgang

Kjenne til konsekvense ved strømigjennomgang og strømulykke

Kjenne til krav om ulike ip/avdekknings grader i ulike miljøe

Kunne oppbyggingen og virkemăten til et nødstrømsannlegg

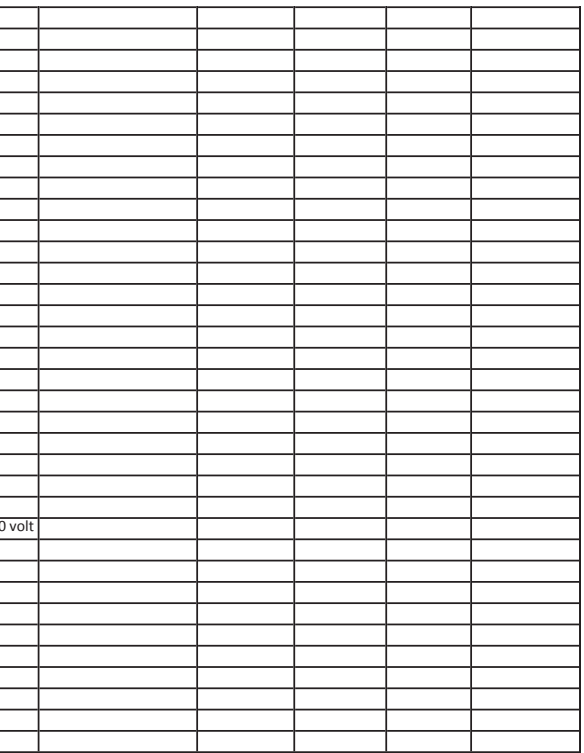




\section{APPENDIX B}

\section{Separate spørsmål for bedrifter og lærere}

\section{Bedriftsundersøkelsen:}

\begin{tabular}{|l||}
\hline Data om bedriften \\
\hline Hvor mange lærlinger innen det aktuelle yrket jobber i bedriften \\
\hline \\
\hline Kunnskaper om sentrale elektriske emner \\
\hline Hvor stor andel av lærlingene kan bruke et multometer når de begynner i bedriften? $0-100 \%$ \\
\hline Hvor stor andel av lærlingene kan foreta en spenningsfallmåling når de begynner i bedriften? 0-100\% \\
\hline Hvor stor andel av lærlingene kan ohms lov når de begynner i bedriften? 0-100\% \\
\hline Hvor stor andel av lærlingene kan lese elektriske tegninger når de begynner i bedrften? $0-100 \%$ \\
\hline
\end{tabular}

\section{Lærerundersøke/sen:}

\begin{tabular}{|l||}
\hline Lærerens bakgrunn \\
\hline Hvor lenge har du jobbet som faglærer (TiP) \\
\hline Hvilken faglig bakgrunn har du fagbrev/industrimekaniker/ ingeniør \\
\hline Er elektro en del av fagbrevet (ja/nei) \\
\hline Kildene for din undervisning \\
\hline GyldendaIs lærebok i tekniske tjenester (ja/nei) \\
\hline Lærebok fra industriskolen (ja/nei) \\
\hline NDLA (ja/nei) \\
\hline Internett (ja/nei) \\
\hline Egen kartlegging av hvilken kompetanse industrien etterspør (ja/nei). Hvia ja hvor mange bedrifter? \\
\hline Din undervisningssituasjon \\
\hline Hvor mange timer undervisning har elevene i elektro i løpet av VG1 TiP? \\
\hline Hvor stor andel av undervisningen er terobasert og hvor stor andel er praktisk (i prosent)? \\
\hline Mener du at noen av elevene på VG1 TiP kan oppfattes som teorisvake? \\
\hline Hvis ja, hvor mange er det i prosent? \\
\hline
\end{tabular}




\section{Appendix C}

\section{APPENDIX C}

\section{Resultat fra bedriftsundersøkelse (del 2)}

\begin{tabular}{|l|r|r|r|}
\hline Batterier & \%viktig & \%kjekt & \% lite \\
\hline Kunne lade og vedlikeholde et bilbatteri & $76 \%$ & $14 \%$ & $10 \%$ \\
\hline forklare hva som skjer når en serie parrallelkobler batterer & $63 \%$ & $21 \%$ & $16 \%$ \\
\hline Kjenne til risikofaktorer ved håndtering av bilbatterier & $68 \%$ & $18 \%$ & $14 \%$ \\
\hline forklare hva apertimer står for/ kapasitet & $37 \%$ & $47 \%$ & $16 \%$ \\
\hline forklare forskjellen mellom start og et forbruksbatteri & $30 \%$ & $38 \%$ & $32 \%$ \\
\hline Forklare oppbyggingen og virkeområdet til Nikkel Kadium batteriet & $5 \%$ & $32 \%$ & $63 \%$ \\
\hline forklare oppbyggingen og virkemåten til litium batterier & $5 \%$ & $39 \%$ & $56 \%$ \\
\hline Forklare oppbyggingen og virkemăten til blybatteriet & $11 \%$ & $40 \%$ & $49 \%$ \\
\hline Forklare oppbyggingen og virkemåten til nikkelhybridbatteriet & $5 \%$ & $42 \%$ & $53 \%$ \\
\hline Forklare oppbyggingen og virkemåten til primær/tørrbatterier & $5 \%$ & $37 \%$ & $58 \%$ \\
\hline matematisk bergne den indre motstanden i et batteri & $3 \%$ & $21 \%$ & $76 \%$ \\
\hline matematisk bergne kortsluttningstrømmen i batterier & $3 \%$ & $21 \%$ & $76 \%$ \\
\hline
\end{tabular}

\begin{tabular}{|l|r|r|r|}
\hline Elektromotorer & & & \\
\hline Koble til og fra en elektromotor & $70 \%$ & $18 \%$ & $12 \%$ \\
\hline Kunne feils $\emptyset$ ke på generator & $50 \%$ & $32 \%$ & $18 \%$ \\
\hline Kunne forklare fabrikkskilt på elektromotorer & $34 \%$ & $39 \%$ & $27 \%$ \\
\hline Kunne forklare oppbygging og virkemåte til en shunt motor & $3 \%$ & $34 \%$ & $63 \%$ \\
\hline Kunne forklare oppbyggingen og virkemåten til en seriemotor & $3 \%$ & $26 \%$ & $71 \%$ \\
\hline Kunne forklare oppbyggingen og virkemăten til en kompoudmotor & $0 \%$ & $21 \%$ & $79 \%$ \\
\hline Kunne forklare oppbyggingen og virkemăten til en asykron motor & $11 \%$ & $21 \%$ & $68 \%$ \\
\hline Kunne forklare oppbyggingen og virkemăten til en trefasmotor & $11 \%$ & $29 \%$ & $60 \%$ \\
\hline Kunne forklare oppbyggingen og virkemåten til likestrømsgenerator & $16 \%$ & $34 \%$ & $50 \%$ \\
\hline kunne forklare oppbyggingen og virkemåten til en vekselstrømsgenerator & $18 \%$ & $37 \%$ & $45 \%$ \\
\hline Kunne bergne motorens virkningsgrad & $8 \%$ & $26 \%$ & $66 \%$ \\
\hline Kunne bergne aktiv og tilsynelatende effekt på en motor & $13 \%$ & $24 \%$ & $63 \%$ \\
\hline
\end{tabular}

\begin{tabular}{|l|r|r|r|}
\hline Elektriske styringer & & & \\
\hline koble kontaktorstyrt start-stopp & $32 \%$ & $13 \%$ & $55 \%$ \\
\hline koble kontaktorstyrt rettningsvenner & $22 \%$ & $14 \%$ & $66 \%$ \\
\hline koble forsinkelseskretser & $16 \%$ & $11 \%$ & $74 \%$ \\
\hline koble stjerne/trekantvender & $11 \%$ & $24 \%$ & $65 \%$ \\
\hline Forklare hva en bruker stjerne trekantvender til & $13 \%$ & $26 \%$ & $61 \%$ \\
\hline Kunne bergne effekten av stjerne trekant kobling & $0 \%$ & $16 \%$ & $84 \%$ \\
\hline kunne koble og programere en frekvensomformer & $8 \%$ & $19 \%$ & $73 \%$ \\
\hline kunne forklare oppbyggingen og virkemåten til en frekvensomformer & $13 \%$ & $16 \%$ & $71 \%$ \\
\hline koble og programere pls & $13 \%$ & $24 \%$ & $63 \%$ \\
\hline koble opp og forklare bruken av kontaktor & $27 \%$ & $27 \%$ & $46 \%$ \\
\hline koble opp og forklare bruken av reeler & $74 \%$ & $16 \%$ & $11 \%$ \\
\hline forklare oppbygging og virkemåte til et bus system & $47 \%$ & $24 \%$ & $29 \%$ \\
\hline koble opp og skjenne bruksområdet til en enpolet bryter & $45 \%$ & $32 \%$ & $24 \%$ \\
\hline koble opp og forklare bruksområdet til en allpolig bryter(toploig) & $42 \%$ & $34 \%$ & $24 \%$ \\
\hline koble opp og forklarte bruksområdet til en rotasjonsmåler & $24 \%$ & $26 \%$ & $50 \%$ \\
\hline koble opp og forklare virkemåten til en luftmassemåler & $47 \%$ & $21 \%$ & $32 \%$ \\
\hline koble opp og forklare bruksområdet til en termisk bryter & $32 \%$ & $32 \%$ & $35 \%$ \\
\hline Koble opp og forklare virkemåten til en dimmer & $26 \%$ & $35 \%$ & $38 \%$ \\
\hline Kunne lese og forstå elektriske tegninger & $79 \%$ & & \\
\hline
\end{tabular}

\begin{tabular}{|l|r|r|r|}
\hline Lederevne og motstand & & & \\
\hline forklarehva en motstand er og dens bruksområde & $66 \%$ & $16 \%$ & $18 \%$ \\
\hline kjenne gjengi fargekoden på elektronikkmotstandet & $3 \%$ & $30 \%$ & $66 \%$ \\
\hline bergne mattematisk motstanden i parrallelkoblede kretser & $24 \%$ & $29 \%$ & $47 \%$ \\
\hline bergne mattematisk motstanden i seriekoblede kretser & $21 \%$ & $29 \%$ & $50 \%$ \\
\hline Forklare forskjellen mellom ohmsk, induktiv og kapasativ motstand & $27 \%$ & $32 \%$ & $41 \%$ \\
\hline Vite når og hvordan en kan bruke et multimeter til å mále motstand & $71 \%$ & $21 \%$ & $8 \%$ \\
\hline vite at kablen tversnitt pảvirker kablens lederevne & $78 \%$ & $19 \%$ & $3 \%$ \\
\hline Vite hvilken krav det stilles til kablens tversnitt i forhold til strømengde & $71 \%$ & $21 \%$ & $8 \%$ \\
\hline Vite hvilken sammenheng det er mellom sikringer og kablens tversnitt & $68 \%$ & $26 \%$ & $5 \%$ \\
\hline vite at lengden på kabelen påvirker kablens lederevne & $58 \%$ & $32 \%$ & $11 \%$ \\
\hline vite at temeraturen påvirker lederevnenog hvordan dette kan utnyttes & $47 \%$ & $39 \%$ & $13 \%$ \\
\hline vite at kablens matriale påvirker kabelens lederevne & $46 \%$ & $32 \%$ & $22 \%$ \\
\hline bergne matrialkonfisienten ved hjelp av mattematikk & $13 \%$ & $13 \%$ & $74 \%$ \\
\hline Vite at dårlige terminerte kabler reduserer kablens lederevne og varmegang & $57 \%$ & $19 \%$ & $24 \%$ \\
\hline forklare hvordan en kan forebygge spenningsfall vedlange kabler & $55 \%$ & $24 \%$ & $21 \%$ \\
\hline
\end{tabular}




\begin{tabular}{|c|c|c|c|}
\hline Ohms lov i teori og i praksis & & & \\
\hline Ohms lov i teorien & $78 \%$ & $18 \%$ & $3 \%$ \\
\hline bruke et multimeter tilá mảle spenning, strøm og motstand & $89 \%$ & $11 \%$ & $0 \%$ \\
\hline Kunne forklare hva Effekt/ Watt står for & $74 \%$ & $26 \%$ & $0 \%$ \\
\hline Kunne forklare hva hestekrefter er & $42 \%$ & $42 \%$ & $16 \%$ \\
\hline kjenne betegenelsen som Watt, Kilowatt og Megawatt & $61 \%$ & $29 \%$ & $11 \%$ \\
\hline Kunne bruke et Wattmeter & $13 \%$ & $42 \%$ & $45 \%$ \\
\hline Kunne forlare hva motstand er & $76 \%$ & $24 \%$ & $0 \%$ \\
\hline Kunne forklare betegelsene Ohm Kilo ohm og mega Ohm & $66 \%$ & $26 \%$ & $8 \%$ \\
\hline forklare hva strøm er & $79 \%$ & $18 \%$ & $26 \%$ \\
\hline kunne forklare begtenelsene milli amp og amp & $73 \%$ & $18 \%$ & $8 \%$ \\
\hline Kunne forklare forskjellen på faktisk og teoreisk strømrettning & $16 \%$ & $34 \%$ & $50 \%$ \\
\hline forklare bohrs atomteorier & $0 \%$ & $13 \%$ & $87 \%$ \\
\hline kunne forklare hvor en normalt bruker likestrøm og vekselstrøm & $44 \%$ & $36 \%$ & $58 \%$ \\
\hline kunne forstå begrepene amplitudeverdi og bunnverdi & $3 \%$ & $39 \%$ & $58 \%$ \\
\hline Elektriske komponenter & & & \\
\hline vite hva dioder brukes til & $59 \%$ & $27 \%$ & $14 \%$ \\
\hline teoretisk forståelse for hvordan en diode er konstruert & $30 \%$ & $32 \%$ & $37 \%$ \\
\hline Vite hva transistorer brukes til & $32 \%$ & $35 \%$ & $32 \%$ \\
\hline teoretisk forstáelse for hvordan en transistor er konstruert & $17 \%$ & $36 \%$ & $47 \%$ \\
\hline vite hva en likeretter brukes til & $41 \%$ & $41 \%$ & $19 \%$ \\
\hline teoretisk forståelse for hvordan en likeretter er konstruert & $19 \%$ & $46 \%$ & $35 \%$ \\
\hline vite hva en transformator brukes til & $32 \%$ & $35 \%$ & $32 \%$ \\
\hline teoretisk forståelse for hvordan en transformator er konstruktert & $14 \%$ & $41 \%$ & $45 \%$ \\
\hline Kondensator vite hva er & $36 \%$ & $33 \%$ & $31 \%$ \\
\hline kunne forklare kondensatorers oppbygging og virkemáte & $16 \%$ & $46 \%$ & $38 \%$ \\
\hline Forklare hva styringsenheten ecu er & $67 \%$ & $11 \%$ & $22 \%$ \\
\hline vite forskjellen mellom ledlamper, fluoriserende og glødelamper & $61 \%$ & $22 \%$ & $17 \%$ \\
\hline Elektrisitet og sikkerhet & & & \\
\hline vite at hovedreglen er at en ikke har lov til å jobbe på elektriske annlegg over 50 volt & $57 \%$ & $30 \%$ & $14 \%$ \\
\hline vite hva en untakksvis har tilatelse til på spenninger over 50 volt & $54 \%$ & $30 \%$ & $16 \%$ \\
\hline Vite hva instruert personel har lov til og gjøre og hva de ikke har lov til & $65 \%$ & $21 \%$ & $14 \%$ \\
\hline vite at kortsluttning kan føre til branne eller brannskader & $86 \%$ & $8 \%$ & $5 \%$ \\
\hline Kjenne til risikoen ved å jobbe i nærheten av høyspentannlegg & $76 \%$ & $14 \%$ & $11 \%$ \\
\hline vite at sikringer er en sikkerhet mot kortsluttning og overbelastning av annleg & $86 \%$ & $11 \%$ & $3 \%$ \\
\hline vite at jording kan redusere risikoen for strømgjennómgang & $70 \%$ & $16 \%$ & $14 \%$ \\
\hline vite at Jordfeilbrytere kan beskyte med farlig strømgjennomgang & $44 \%$ & $42 \%$ & $11 \%$ \\
\hline Kjenne til konsekvense ved strømigjennomgang og strømulykker & $70 \%$ & $19 \%$ & $11 \%$ \\
\hline Kjenne til krav om ulike ip/avdekknings grader i ulike miljøer & $38 \%$ & $24 \%$ & $38 \%$ \\
\hline Kunne oppbyggingen og virkemåten til et nødstrømsannlegg & $35 \%$ & $22 \%$ & $43 \%$ \\
\hline
\end{tabular}

\section{Appendiks D}

\section{Resultat fra lærerundersøkelse (del 1)}

\begin{tabular}{|c|c|c|c|c|c|c|c|c|c|c|c|c|c|c|c|}
\hline & {$[1$} & {$[2$} & 13 & 44 & 5 & L6 & L77 & $\overline{18}$ & {$[9$} & L10 & L11 & {$[12$} & {$[13$} & L14 & L15 \\
\hline Antall år som faglærer & 11 & & 8 & 21 & 8 & 17 & 4 & 19 & 23 & 28 & 2,5 & 5 & 10 & & \\
\hline Er elektro del av fagbrevet & ta & Nei & ia & $\mathrm{ta}$ & $\mathrm{a}$ & a & Ja & Nei & Nei & Nei & $\mathrm{Ja}$ & $\mathrm{a}$ & Nei & & \\
\hline Kartlegging av bedriftenes behov & ta & Nei & ta & nei & ta & & Nei & & Nei & $\sqrt{a}$ & $\mathrm{a}$ & Nei & Ja & & \\
\hline Antall timer elektro på TiP VG1 & 70 & 25 & 84 & 70 & 60 & 60 & 70 & 70 & 20 & 40 & 70 & 25 & & & \\
\hline Andel teoretisk undervisning & $50 \%$ & & $25 \%$ & $60 \%$ & $50 \%$ & $70 \%$ & $30 \%$ & $30 \%$ & $80 \%$ & $20 \%$ & $100 \%$ & $20 \%$ & $50 \%$ & & \\
\hline Antall tema som undervises & 58 & 62 & 53 & 51 & 26 & 73 & 51 & 57 & 42 & 77 & 60 & 22 & 51 & 54 & 00 \\
\hline Antall tema ikke viktig & 12 & 15 & 7 & 11 & 2 & 21 & 16 & 9 & 5 & 25 & 11 & 1 & 12 & & 21 \\
\hline Prosent ikke viktig & 21 & 24 & 13 & 22 & 8 & 29 & 31 & 16 & 12 & 32 & 18 & 5 & 24 & 15 & 32 \\
\hline Tema per undervisr & 0,8 & 2,5 & 0,6 & 0,7 & 0,4 & 1,2 & 0,7 & 0,8 & 2,1 & 1,9 & 0,9 & 0,9 & & & \\
\hline
\end{tabular}

